\title{
The investigation of the relationship between Turkish EFL teachers' technological pedagogical content knowledge skills and attitudes towards technology
}

\author{
İshak Kozikoğlu a * (iD), Nuri Babacan ${ }^{\text {b }}$ (iD \\ ${ }^{a}$ Van Yüzüncü Yll University, Van/Turkey \\ ${ }^{b}$ Van Yüzüncü Yll University, Van/Turkey
}

\section{APA Citation:}

Kozikoğlu, İ., \& Babacan, N. (2019). The investigation of the relationship between Turkish EFL teachers' technological pedagogical content knowledge skills and attitudes towards technology. Journal of Language and Linguistic Studies, 15(1), 20-33.

Submission Date:03/08/2018

Acceptance Date:23/01/2019

\begin{abstract}
The technology has entered our life day by day and the effects of this are felt in English language teaching and learning, as well as it does in the education. This study aims to investigate the relationship between Turkish EFL teachers' technological pedagogical content knowledge (TPACK) skills and attitudes towards technology. This research also examined whether Turkish EFL teachers' TPACK skills and their attitudes towards technology differs according to the gender, FATIH project training and professional experience. This research was conducted with 721 Turkish EFL teachers working in 81 provinces of Turkey. Correlational survey model was used in this study. "TPACK Implementation Scale" and "Attitude Scale towards Technology" were used as data collection tools. Arithmetic mean, standard deviation, $\mathrm{t}$ test, ANOVA and Pearson Product Moment Correlation Coefficient were used in data analysis. As a result of the study, it was determined that Turkish EFL teachers' TPACK skills and attitudes towards technology were at high level. While the attitudes of Turkish EFL teachers towards technology did not show a significant difference according to gender, FATIH project training and professional experience, the female teachers and the teachers who got the FATIH Project training had higher TPACK skills. However, it was found that TPACK skills of the teachers did not differ significantly according to the professional experience. In addition, it was concluded that there is a low, positive and significant relationship between teachers' TPACK skills and attitudes towards technology.
\end{abstract}

(C) 2019 JLLS and the Authors - Published by JLLS.

Keywords: Technological pedagogical content knowledge (TPACK); attitudes towards technology; Turkish EFL teachers; technology; Fatih project

\section{Introduction}

The century we live in is known as technological age. The rapid progress of technology has been effective in all areas of our lives. This effect is also felt in the learning habits of Z-generation individuals around the world and, consequently, in their education systems. As a result of these reflections, the use

\footnotetext{
* Corresponding author.

E-mail address: ishakkozikoglu@yyu.edu.tr
} 
and integration of technology in education have become inevitable. With the effects of technology in education system, the duties and responsibilities expected from teachers have also changed. This expectation includes not only teachers' technology use but also effective technology integration in teaching activities (Cüre and Özdener, 2008). In this context, it is necessary for the students and teachers not only to have computer skills, but also to have a certain level of knowledge and awareness about information and communication technologies (Öztürk, 2013). Recently, the use of ICT (Information and Communication Technologies) in English classes has had a considerable impact on English language teaching and learning (Günüç and Babacan, 2017). The important role of ICT in teaching English requires Turkish EFL teachers to have technological knowledge and skills to plan their lessons and implement them. In other words, Turkish EFL teachers who want to integrate technology into their lessons should be competent in terms of not only content and pedagogical knowledge but also potential of the technology (Öz, 2015). In this context, the concept that Schulman (1987) defines as Pedagogical Content Knowledge (PCK) and comprises teacher competences was later described by Koehler and Mishra (2005) as Technological Pedagogical Content Knowledge (TPACK) with the addition of technology.

TPACK has several definitions in the literature. Koehler and Mishra (2006) defined TPACK as being able to use technology to support pedagogical techniques with technology, to help students solve problems they encounter while learning, to consolidate existing knowledge, and to work on technology at the point of maintaining new knowledge. Niess (2008) defined TPACK as the way teachers use 21st century technologies to plan, organize and adapt class conditions according to the student needs. Timur and Taşar (2011) defined TPACK as effective integration of educational technologies with Pedagogical Content Knowledge in classes. With these definitions, TPACK can be defined as effective usage of the technology in the teaching-learning process and teachers' enrichment of their pedagogical content knowledge with technology.

Mishra and Koehler (2006) explained the TPACK framework with seven components which is presented in Figure 1 below.

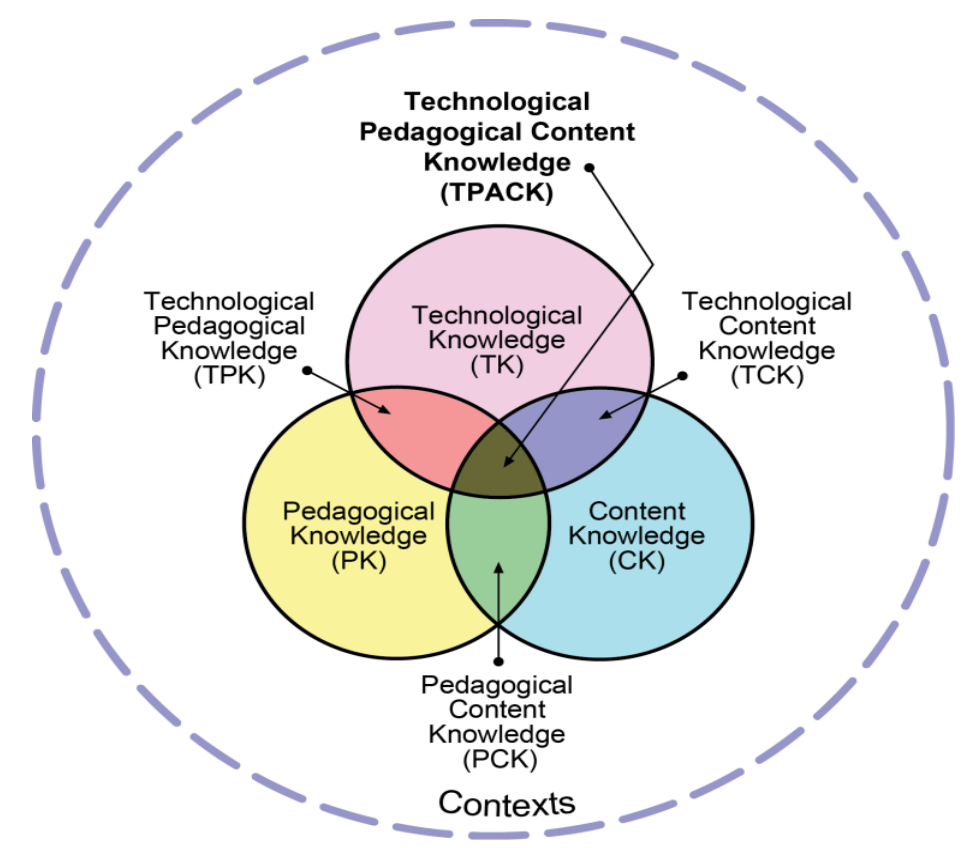

Figure 1. Schematic representation of TPACK framework (Koehler, 2011) 
As it can be seen in Figure 1, the three basic knowledge that a teacher should have according to the TPACK framework are Technological Knowledge (TK), Pedagogical Knowledge (PK) and Content Knowledge (CK). The intersection of these three components that are Pedagogical Content Knowledge (PCK), Technological Pedagogical Knowledge (TPK), Technological Content Knowledge (TCK) and Technological Pedagogical Content Knowledge (TPACK) have the same importance (Koehler and Mishra, 2005, 2008, 2009; Mishra and Koehler, 2006).

The changes in learning habits of the students have led to different expectations in the field of foreign language as well as in many areas. The most important task considering these expectations falls to the teachers. The use of technology in education, and especially in English teaching, continues to be a new field of study because of the fact that large-scale technological advances bring new teaching possibilities (Al-Zaidiyeen, Mei and Fook, 2010). ICT has not only changed the role of teachers in the classroom, but also has provided a number of software and web sites that can be used for educational purposes (Ruthven, Nennessy and Deaney, 2005; Seal and Przasnyski, 2001). Technological developments have forced Turkish EFL teachers to acquire and develop new skills and abilities in order to succeed in the new context (Lewis, 2009).

The skills primarily expected from the Turkish EFL teachers to have are active use of technology in the classes, encouraging students to learn English by using technology, motivating learners to use English and improving students' speaking, listening, writing and reading skills. Teachers need to change their teaching methods and techniques in order to meet these expectations. In this context, teachers use a variety of technological tools such as interactive boards, tablets, Educational Information Network (a network created by the Ministry of National Education in Turkey) and Web 2.0 tools in English classes. In today's age of information and technology, it is necessary for teachers to follow technological developments for a developed society and successful education and use technology to contribute to the effective learning of students. In other words, it is very important that they have sufficient TPACK skills and they continuously improve their TPACK skills throughout their professional life (Kaya and Yilayaz, 2013). In this context, various in-service trainings such as courses and seminars are provided by the Ministry of National Education in order to increase the use of technology in lessons. However, in order to enable teachers to use technology effectively in their teaching-learning process, attitudes towards technology use in education are of utmost importance as well as having TPACK skills.

The education system based on rote learning has become ineffective for long years. Rote learning has given its place to an education system in which there are creative and unique individuals who think, inquire, construct knowledge and produce solutions to the problems. Considering the current use of information and communication technology, the use of ICT and therefore the attitudes of the individuals towards the use of ICT which play an important role in this change have been investigated by many researchers. The student achievement gained by using computer technology is largely related to the attitudes of teachers and their willingness to adopt technology (Teo, 2006). Hazzan (2000) concluded that teachers who use technology in their own learning show a positive attitude towards the technology. Slough and Chamblee (2000) pointed out that teachers who experience the positive contribution of technology in teaching processes are more willing to use technology in teaching learning processes. The more teachers have knowledge about technology, the more positive attitudes they have towards technology (Akkoyunlu, 1996; Coffland, 2000). In the light of all these studies, it is seen that teachers' attitudes toward technology are very essential as well as technological pedagogical content knowledge.

As noted above, it seems that the use of technology in foreign language education is very important, and it is seen that today's Turkish EFL teachers need to have TPACK skills and a positive attitude towards technology in order to ensure effective learning. In this case, it is necessary to determine Turkish EFL teachers' TPACK skills and attitudes towards technology. 


\subsection{The aim and importance of the study}

The aim of this study is to investigate the relationship between Turkish EFL teachers' TPACK skills and attitudes towards technology. For this purpose, the following questions are addressed.

1. What is the level of Turkish EFL teachers' TPACK skills and attitudes towards technology?

2. Do Turkish EFL teachers' TPACK skills and attitudes towards technology differ significantly according to gender, Fatih project training and professional experience?

3. Is there a significant relationship between the Turkish EFL teachers' TPACK skills and their attitudes towards technology?

TPACK is a concept that includes the reflection of technology on teaching-learning processes and therefore the ability of teachers to turn this reflection into an advantage. When the literature in Turkey is examined, it is seen that there is a limited number of TPACK studies conducted with teachers of different branches and prospective teachers (Bal and Karademir, 2013; Doğru and Aydın, 2017; Mutluoğlu and Erdoğan, 2016; Sancar-Tokmak, Yavuz-Konakman and Yanpar-Yelken, 2013). Apart from these studies, it was found to be a study conducted by Solak and Çakır (2014) with a total of 137 prospective English teachers. However, apart from this study, no TPACK study on Turkish EFL teachers has been found. When considering the importance of technology use and teachers 'attitudes toward technology in English teaching, it is thought that this study will contribute to the related literature in terms of determining Turkish EFL teachers' TPACK skills, their attitudes towards technology and investigating the relationship between these two variables. Furthermore, this study includes 721 Turkish EFL teachers working in different provinces across Turkey and this makes the study important in terms of determining the overall profile of Turkish EFL teachers' TPACK skills and attitudes towards technology in Turkey.

\section{Method}

\subsection{Research model}

Correlational survey model is used in this study. In correlational survey model, the existence and/or the level of relationship between two or more variables (situations or events) are determined (Karasar, 2015; Serin and Buluç, 2014). As it is aimed in this study to determine the relationship between Turkish EFL teachers' TPACK skills and attitudes towards technology, correlational survey model is thought to be suitable for the aim of the study.

\subsection{Study group}

The study group of this study consists of 721 Turkish EFL teachers from 81 provinces of Turkey's. Convenience sampling method was used in the determination of the study group. In convenience sampling method, the researcher works on the group that is easy to access, thus making this study practical (Yıldırım and Şimşek, 2013). In determination of the study group, participants' voluntariness was taken into consideration. The distribution of the Turkish EFL teachers' personal characteristics is presented in Table 1. 
Table 1. The distribution of the Turkish EFL teachers' personal characteristics

\begin{tabular}{llll}
\hline Personal Characteristics & Category & Number (N) & Percent (\%) \\
\hline \multirow{2}{*}{ Gender } & Female & 616 & 85.4 \\
& Male & 105 & 14.6 \\
\hline \multirow{2}{*}{ Professional experience } & $1-5$ years & 300 & 41.6 \\
& 6-10 years & 174 & 24.1 \\
& 11 and more & 247 & 34.3 \\
\hline \multirow{2}{*}{ FATIH project training } & Yes & 447 & 62 \\
& No & 274 & 38 \\
\hline
\end{tabular}

As seen in Table 1, 105 (14.6\%) of the participants are male and $616(85.4 \%)$ are female. $300(41.6 \%)$ of the participants have $1-5$ years, 174 teachers $(24.1 \%)$ have $6-10$ years and 247 teachers $(34.3 \%)$ have 11 years and more professional experience. In addition, $447(62 \%)$ of the participants got the Fatih Project training while 274 (38\%) did not get the Fatih Project training.

\subsection{Data collection tools and data collection process}

In this study, "Attitude Scale towards Technology" was used to determine the attitudes of English teachers towards technology, and "Technological Pedagogical Content Knowledge Implementation Scale" was used to determine teachers' levels of TPACK skills. Explanations about data collection tools are presented below:

Attitude scale towards technology: The Attitude Scale towards Technology developed by Yavuz (2005) is used to determine the attitude of teachers and prospective teachers toward technology. The 5-point Likert-type scale consists of 19 items. The Cronbach Alpha internal consistency coefficient of the scale is .87 , which is found to be .85 in this study. These values indicate that this data collection tool is valid and reliable.

Technological pedagogical content knowledge implementation scale: This scale developed by Yeh, Hsu, Wu, Hwang and Lin (2013) and adapted to Turkish by Ay (2015), measures teachers' skills concerning implementation of technological pedagogical content knowledge. The 5-point Likert-type scale consists of 22 items and five sub-dimensions including learners, subject area, program design, practical teaching and evaluations. The Cronbach Alpha internal consistency coefficient of the scale is .89, which is found to be .97 in this study. These values indicate that this data collection tool is valid and reliable.

The data were collected by using Google Forms, one of the most commonly used tools in today. The personal information form and scales on the Google Form were posted via social networks, forum sites, e-mail and Whatsapp by creating an online link and the online survey has been online for approximately two months. The data were collected online.

\subsection{Data analysis}

In this study, the arithmetic mean and standard deviation values of the scale scores were examined in order to determine Turkish EFL teachers' attitudes towards technology and TPACK skill levels. These values were interpreted as 'very low' between 1-1.79, 'low' between 1.80-2.59, 'moderate' between 2.60 and 3.39, 'high' between 3.40 and 4.9 and 'very high' between 4.20 and 5.00. As it was found that the data show normal distribution as a result of the normality test, t-test was used for gender and Fatih project training variables, and ANOVA was used for professional experience. In addition, Pearson 
Product Moments Correlation Coefficients were examined to determine the relationship between teachers' TPACK skills and attitudes towards technology.

\section{Results}

\subsection{Results concerning the first sub-problem}

The arithmetic mean and standard deviation values concerning the first sub-problem which is "What is the level of Turkish EFL teachers' TPACK skills and attitudes towards technology?" are presented in Table 2.

Table 2. The mean and standard deviation values concerning the first sub-problem

\begin{tabular}{llc}
\hline Scales and sub dimensions & $\bar{X}$ & ss \\
\hline TPACK (Total) & 3.46 & 0.81 \\
Learners & 3.42 & 0.83 \\
Subject Area & 3.64 & 0.87 \\
Program Design & 3.40 & 0.85 \\
Applied Teaching & 3.52 & 0.84 \\
Evaluations & 3.47 & 0.89 \\
Attitudes Towards Technology & 4.24 & 0.41 \\
\hline
\end{tabular}

When Table 2 are examined, it was found that TPACK skills of Turkish EFL teachers in total scale ( $\bar{X}=3.46)$, its sub-dimensions that are learners $(\bar{X}=3.42)$, subject area $(=3.64)$, program design $(\bar{X}$ $=3.40$ ), applied teaching ( $\bar{X}=3.52)$, evaluations $(\bar{X}=3.47)$, and their attitudes towards technology ( $\bar{X}=4.24)$ are at high level.

\subsection{Results concerning the second sub-problem}

Concerning the second sub-problem of the study, which is "Do Turkish EFL teachers' TPACK skills and attitudes towards technology differ significantly according to gender, Fatih project training and professional experience?", t-test results according to the gender are presented in Table 3:

Table 3. T-test results according to the gender concerning the second sub-problem

\begin{tabular}{lllccccc}
\hline Scales & Gender & $\boldsymbol{N}$ & $\bar{X}$ & $\boldsymbol{s}$ & $\boldsymbol{s d}$ & $\boldsymbol{t}$ & $\boldsymbol{p}$ \\
\hline \multirow{2}{*}{ TPACK Skills } & Female & 616 & 3.43 & 0.81 & 719 & $-2,99$ & .003 \\
& Male & 105 & 3.68 & 0.79 & & & .217 \\
\hline Attitudes towards & Female & 616 & 4.23 & 0.41 & 719 & $-1,23$ & \\
Technology & Male & 105 & 4.28 & 0.40 & & & \\
\hline
\end{tabular}

As seen in Table 3, Turkish EFL teachers' TPACK skills differ significantly in favor of male teachers according to gender $(\mathrm{t}(719)=-1.23, \mathrm{p}>.05)$, while their attitudes towards technology do not show significant difference according to gender $(\mathrm{t}(719)=-2.99, \mathrm{p}<.05)$. Concerning the second sub-problem of the study, t-test results according to Fatih Project training are presented in Table 4: 
Table 4. T-test results according to the Fatih project training concerning the second sub-problem

\begin{tabular}{llllllll}
\hline Scales & Fatih Project training & $\boldsymbol{N}$ & $\bar{X}$ & $\boldsymbol{s}$ & $\boldsymbol{s} \boldsymbol{d}$ & $\boldsymbol{t}$ \\
\hline \multirow{2}{*}{ TPACK Skills } & Yes & 447 & 3.52 & 0.77 & 719 & 2.29 & .022 \\
& No & 274 & 3.37 & 0.87 & & & \\
\hline Attitudes towards & Yes & 447 & 4.25 & 0.40 & 719 & .84 & .399 \\
Technology & No & 227 & 4.22 & 0.41 & & & \\
\hline
\end{tabular}

In seen in Table 4, it was found that Turkish EFL teachers' attitudes towards technology do not show significant difference according to Fatih Project training ( $\left({ }_{719}\right)=, 84$, p> .05), whereas their TPACK skills show significant difference in favor of the teachers who got Fatih Project training $(\mathrm{t}(719)=2.29, \mathrm{p}$ $<.05)$. The ANOVA results according to the professional experience concerning the second sub-problem are presented in Table 5:

Table 5. ANOVA results according to the professional experience concerning the second sub-problem

\begin{tabular}{|c|c|c|c|c|c|c|c|c|c|c|}
\hline \multicolumn{5}{|c|}{ Descriptive Statistics } & \multicolumn{6}{|l|}{ ANOVA Results } \\
\hline Scales & $\begin{array}{l}\text { Professional } \\
\text { Experience }\end{array}$ & $N$ & $\overline{\bar{X}}$ & $S$ & $\begin{array}{l}\text { Source of } \\
\text { Variance }\end{array}$ & $\begin{array}{l}\text { Sum of } \\
\text { Squares }\end{array}$ & $s d$ & $\begin{array}{l}\text { Mean of } \\
\text { Squares }\end{array}$ & $F$ & $p$ \\
\hline \multirow{3}{*}{$\begin{array}{l}\text { TPACK } \\
\text { Skills }\end{array}$} & $1-5$ years & 300 & 3.51 & 0.79 & Between Groups & 1.324 & 2 & .662 & 1.004 & .367 \\
\hline & $6-10$ years & 174 & 3.41 & 0.79 & Within Groups & 473.380 & 718 & .659 & & \\
\hline & 11 and more & 247 & 3.44 & 0.85 & Total & 474.703 & 721 & & & \\
\hline \multirow{3}{*}{$\begin{array}{l}\text { Attitude } \\
\text { Towards } \\
\text { Technology }\end{array}$} & $1-5$ years & 300 & 4.27 & 0.39 & Between Groups & .662 & 2 & .331 & 2.003 & .136 \\
\hline & $6-10$ years & 174 & 4.21 & 0.41 & Within Groups & 118.695 & 718 & .165 & & \\
\hline & 11 and more & 247 & 4.21 & 0.42 & Total & 119.357 & 721 & & & \\
\hline
\end{tabular}

$p>.05$

As seen in Table 5, it was found that the teachers' TPACK skills $(\mathrm{F}(2,718)=1.004, \mathrm{p}>.05)$ and their attitudes toward technology $(\mathrm{F}(2,718)=2.003, \mathrm{p}>.05)$ do not show significant difference according to professional experience.

\subsection{Results concerning the third sub-problem}

The Pearson Product Moment Correlation Coefficients calculated for investigating the relationship between Turkish EFL teachers' TPACK skills and attitudes towards technology concerning the third sub-problem that is "Is there a significant relationship between Turkish EFL teachers' TPACK skills and their attitudes towards technology?" are presented in Table 6: 
Table 6. Pearson Product Moment Correlation Coefficients concerning Turkish EFL teachers' TPACK skills and attitudes towards technology

\begin{tabular}{|c|c|c|c|}
\hline Variables & & TPACK Skills & $\begin{array}{c}\text { Attitudes Towards } \\
\text { Technology }\end{array}$ \\
\hline TPACK Skills & & 1.00 & \\
\hline $\begin{array}{l}\text { Attitudes } \\
\text { Technology }\end{array}$ & towards & $.197^{* *}$ & 1.00 \\
\hline
\end{tabular}

$p<.05 *, p<.01 * *$

According to Table 6, there is a low, positive and significant relationship between Turkish EFL teachers' TPACK skills and attitudes towards technology $(r=.197 ; \mathrm{p}<.01)$.

\section{Discussion, Conclusion and Suggestions}

In this study, it was concluded that Turkish EFL teachers have a high level of TPACK skills and attitude towards technology. This result supports similar study results in the literature. In many studies in the literature, it is stated that teachers' TPACK skills (Archambault and Crippen, 2009; Barış, 2015; Bozkurt, 2016; Jordan, 2011; Semiz and İnce, 2012) and their attitudes towards technology (AlbayrakSar1, Canbazoğlu-Bilici, Baran and Özbay, 2016; Al-Zaidiyeen, Mei and Fook, 2010; Oktay and Çakır, 2012) are high. Unlike this research, Pamuk (2012) concluded that beginning teachers' TPACK skills are at low level due to the lack of experience.

Based on the results of this research, it can be said that Turkish EFL teachers have a high level of TPACK implementation skills and have a positive attitude towards using technology. Studies in the literature reveal the role and importance of the technology use in teaching and learning English (Günüç and Babacan, 2017; Li, 2005; Reagin, 2004; Warschauer, 2002). Positive attitudes of Turkish EFL teachers towards technology and teachers' TPACK skills are very important in terms of effective and appropriate use of technology in foreign language classes and positive effects of students' performance (Donnelly, McGarr, and O’Reilly, 2011; Ertmer, 2005; Günüç and Babacan, 2017; Hew and Brush, 2007). Therefore, Turkish EFL teachers' high level of TPACK skills and positive attitudes towards technology can be seen as a positive result in terms of technology integration in English teaching and effective language learning.

As a result of this research, it was concluded that Turkish EFL teachers' attitudes towards technology do not differ significantly according to gender, while the male teachers have a higher level of TPACK skills than the female teachers. This result shows parallelism with the results of similar studies in the literature. Jang and Tsai (2013) concluded in their study conducted with Taiwanese teachers that male teachers have higher TPACK skills than female teachers. Similarly, Solak and Çakır (2014) found a significant difference in favor of male prospective teachers in their study with 137 prospective English teachers. According to a study by Bal and Karademir (2013) conducted with social studies teachers, it was concluded that male teachers are more likely to use technology in their lessons than female teachers. Unlike this study, in the study by Şad, Akgül and Delican (2015) conducted with 4th grade students of education faculty, it was found that there is not any significant difference in the students' TPACK competency level according to gender. In this case, it is seen that different results have been reached in the studies concerning the gender. The differences in the characteristics of the sample or the study group, the number of participants included in the survey and the gender distribution can be interpreted as the reason for these differences. Based on the results of this study, it can be said that female and male 
teachers have similar attitudes towards technology. Furthermore, in this study, the higher level of TPACK skills of male teachers compared to female teachers can be interpreted as male teachers have better skills in using technology and integrating it in English teaching than female teachers.

In this study, it was concluded that the Turkish EFL teachers' attitudes towards technology do not differ significantly according to Fatih Project training, whereas the teachers who got Fatih Project training have higher level of TPACK skills than the teachers who did not get Fatih Project training. Parallel to the results of this research, similar results were reached in the study of Bal and Karademir (2013) conducted with social studies teachers. On the other hand, according to the study conducted by Pamuk, Çakır, Ergun, Yılmaz and Ayas (2013), the superficial implementation of Fatih Project training causes the teachers not to achieve the desired efficiency in the use of technology. As a result of this research, it can be stated that Fatih project training provides teachers with positive contributions to their TPACK skills. Fatih Project training aims to integrate the education system with advanced technologies, to support with innovations, to create student-centered and project-based learning environment using information technology (MEB, 2009). According to the results of this study, it can be said that Fatih Project training attained its purpose in terms of positive reflections of TPACK skills of the Turkish EFL teachers.

As a result of the research, it was concluded that the teachers' attitudes toward technology and TPACK skills do not show any significant difference according to their professional experience. Unlike this study, Lee and Tsai (2010) found that teachers with low professional experience had higher TPACK performances than teachers with more professional experience. On the other hand, Jang and Tsai (2012) reported that mathematics teachers with higher professional experience had a higher level of TPACK skills. In addition, according to the study of Bal and Karademir (2013), the attitudes of teachers towards technology, who are with less than 20 years of experience, were higher. It is seen that Turkish EFL teachers have a high level of TPACK skills and attitudes towards technology without regard to their professional experience. Based on the results of this research, it can be said that the Turkish EFL teachers' TPACK skills and their attitudes toward technology do not differ according to professional experience.

In addition, it was concluded that there is a low, positive and significant relationship between Turkish EFL teachers' TPACK skills and their attitudes towards technology. This study, conducted with Turkish EFL teachers, supports the similar study results in the literature. In the study conducted by Bilgin, Tatar and Ay (2012), it was determined that there is a significant relationship between prospective teachers' attitudes towards technology and their technological pedagogical content knowledge, and prospective teachers' positive attitudes towards technology explained $28.1 \%$ of variance in their TPACK skills. Ay (2015), in his study with teachers, determined that the attitude towards technology influences TPACK skills and there is a significant relationship between attitudes towards technology and TPACK skills. Parallel to this result, in the study conducted by Albayrak-Sar1 et al. (2016), it was found that teachers' attitudes towards technology predicted TPACK skills significantly. Besides, as a result of Abbitt's (2011) study with beginning teachers, it was determined that there is a significant relationship between teachers' attitudes towards technology and TPACK skills. From these results, it can be said that TPACK skills and attitudes towards technology are closely related. In this case, it can be said that the attitude towards technology affects TPACK skills, in other words, the more positive attitude towards technology anyone has, the more TPACK skills he/she has. Hence, it can be said that Turkish EFL teachers need to develop positive attitudes towards technology so that they can integrate technology effectively into English teaching.

In the light of these research results, it is seen that Turkish EFL teachers' attitudes toward technology and TPACK skills as a 21st-century necessity are at a high level. Fatih Project trainings have positive contributions to this result. Teachers need to integrate and use technology effectively in the lessons 
rather than just knowing them. The Ministry of National Education has important duties in terms of helping teachers recognize and integrate new technologies. As a matter of fact, the ministry organizes in-service courses and seminars for development of the teachers. In order for the courses and seminars to be more effective, increasing the quality, dissemination and control of these practices is of great importance. It also turned out that there is a positive relationship between attitudes towards technology and TPACK skills. Therefore, in order to develop positive attitudes towards the use of technology, it is suggested to attach the necessary importance for the use of technology during in-service and pre-service teacher education and to organize trainings in this direction. This study was conducted with 721 Turkish EFL teachers in 81 provinces of Turkey. In further studies, the technological tools that can be used in English classes and the effects of these tools can be studied, as well as the TPACK skills of different branch teachers.

\section{References}

Abbitt, J. T. (2011). An investigation of the relationship between self-efficacy beliefs about technology integration and technological pedagogical content knowledge (TPACK) among preservice teachers. Journal of Digital Learning in Teacher Education, 27(4), 134-143.

Akkoyunlu, B. (1996). Öğrencilerin bilgisayara karşı tutumları. Eğitim ve Bilim, 20(100), 15-29.

Alayyar, G. M., Fisser, P. and Voogt, J. (2012). Developing technological pedagogical content knowledge in pre-service science teachers: Support from blended learning. Australasian Journal of Educational Technology, 28(8).

Albayrak-Sarı, A., Canbazoğlu-Bilici, S., Baran, E. and Özbay, U. (2016). Farklı branşlardaki ögretmenlerin teknolojik pedagojik alan bilgisi (TPAB) yeterlikleri ile bilgi ve iletişim teknolojilerine yönelik tutumları arasındaki ilişkinin incelenmesi. Eğitim Teknolojisi Kuram ve Uygulama, 6(1).

Al-Zaidiyeen, N. J., Mei, L. L. and Fook, F. S. (2010). Teachers' attitudes and levels of technology use in classrooms: The case of Jordan schools. International Education Studies 3(2), 211.

Archambault, L., and Crippen, K. (2009). Examining TPACK among K-12 online distance educators in the United States. Contemporary Issues in Technology and Teacher Education, 9(1), 71-88.

Ay, Y. (2015). Öğretmenlerin teknolojik pedagojik alan bilgisi (TPAB) becerilerinin uygulama modeli bağlamında değerlendirilmesi (Yayınlanmamış doktora tezi). Osmangazi Üniversitesi Eğitim Bilimleri Enstitüsü, Eskişehir.

Bal, M. S. and Karademir, N. (2013). Sosyal bilgiler öğretmenlerinin teknolojik pedagojik alan bilgisi (TPAB) konusunda öz-değerlendirme seviyelerinin belirlenmesi. Pamukkale Üniversitesi Ĕgitim Fakültesi Dergisi, 34(2), 15-32.

Baris, M. F. (2015). European teachers' technological pedagogical content knowledge (TPCK) and educational use of web technologies. European Journal of Educational Research, 4(4), 149-155.

Bilgin, İ., Tatar, E., and Ay, Y. (2012). Sınıf öğretmeni adaylarının teknolojiye karşı tutumlarının teknolojik pedagojik alan bilgisi (TPAB)'ne katkısının incelenmesi. X. Ulusal Fen Bilimleri ve Matematik Eğitimi Kongresi Bildiriler Kitabı, 125.

Bozkurt, N. (2016). Tarih Öğretmeni Adaylarının Teknolojik Pedagojik Alan Bilgisine Yönelik Özgüvenlerinin Belirlenmesi/Determination of Self-Confidence for Technological Pedagogical 
Content Knowledge of Pre-Service History Teacher. Mustafa Kemal Üniversitesi Sosyal Bilimler Enstitüsü Dergisi, 13(33).

Coffland, D. and Strickland, A. W. (2000). Factors related to teacher use of technology in secondary geometry instruction. In Society for Information Technology ve Teacher Education International Conference (pp. 1048-1054). Association for the Advancement of Computing in Education (AACE).

Cüre, F. and Özdener, N. (2008). Öğretmenlerin bilgi ve iletişim teknolojileri (BİT) uygulama başarıları ve BİT’e yönelik tutumları. Hacettepe Üniversitesi Eğitim Fakültesi Dergisi, 34(34).

Doğru, E. and Aydın, F. (2017). Coğrafya öğretmenlerinin teknolojik pedagojik alan bilgisi ile ilgili yeterliliklerinin incelenmesi/examining the skills of geography teachers' technological pedagogical content knowledge. Journal of History Culture and Art Research, 6(2), 485-506.

Donnelly, D., McGarr, O. and O'Reilly, J. (2011). A framework for teachers' integration of ICT into their classroom practice. Computers \& Education, 57(2), 1469-1483.

Ertmer, P. A. (2005). Teacher pedagogical beliefs: The final frontier in our quest for technology integration? Educational Technology Research and Development, 53(4), 25-39.

Günüç, S. and Babacan, N. (2017). Technology integration in English language teaching and learning. The Journal of Teaching English for Spesific and Academic Purposes. 5(2), 349-358.

Hazzan, O. (2000). Attitudes of prospective high school mathematics teachers towards integrating information technologies in their future teaching. In Society for Information Technology ve Teacher Education International Conference (pp. 1582-1587). Association for the Advancement of Computing in Education (AACE).

Hew, K. F. and Brush, T. (2007). Integrating technology into K-12 teaching and learning: Current knowl- edge gaps and recommendations for future research. Education Technology Research \& Development, 55, 223-252

Jang, S.-J., and Tsai, M.-F. (2012). Exploring the TPACK of Taiwanese elementary mathematics and science teachers with respect to use of interactive whiteboards. Computers \& Education, 59(2), 327338.

Jang, S. J. and Tsai, M. F. (2013). Exploring the TPACK of Taiwanese secondary school science teachers using a new contextualized TPACK model. Australasian Journal of Educational Technology, 29(4).

Jordan, K. (2011). Beginning Teacher Knowledge: Results from a Self-Assessed TPACK Survey. Australian Educational Computing, 26(1), 16-26.

Karasar, N. (2015). Araştırmalarda rapor hazırlama (19. bask1). Ankara: Nobel Akademik Yayınc1lık.

Kaya, Z. and Yılayaz, Ö. (2013). Öğretmen eğitiminde teknoloji entegrasyonu modelleri ve teknolojik pedagojik alan bilgisi. Batı Anadolu Eğitim Bilimleri Dergisi 4(8), 57-83.

Koehler, M. (2011). TPACK. 26. 03. 2018 tarihinde TPACK ORG: http://tpack.org/ adresinden alınmıştır.

Koehler, M. J. and Mishra, P. (2005). What happens when teachers design educational technology? The development of technological pedagogical content knowledge. Journal of educational computing research, 32(2), 131-152. 
Koehler, M. J. and Mishra, P. (2008). Introducing TPCK. AACTE committee on innovation and technology (Ed.), The handbook of technological pedagogical content knowledge (TPCK) for educators (pp. 3-29). Mah-wah, N]: Lawrence Erlbaum Associates.

Koehler, M. and Mishra, P. (2009). What is technological pedagogical content knowledge (TPACK)?. Contemporary Issues in Technology and Teacher Education, 9(1), 60-70.

Lee, M. H., and Tsai, C. C. (2010). Exploring teachers' perceived self-efficacy and technological pedagogical content knowledge with respect to educational use of the world wide web. Instructional Science, 38, 1-21.

Lewis, G. (2009). Bringing Technology into the Classroom. Oxford: Oxford University Press.

Li, W. A. N. G. (2005). The advantages of using technology in second language education. T.H.E. Jounral, 32(10), 38-42.

MEB (2009). Milli Eğitim Bakanlığı 2010-2014 stratejik planı. Ankara: Milli Eğitim Bakanlığı.

Mishra, P. and Koehler, M. J. (2006). Technological pedagogical content knowledge: A framework for teacher knowledge. Teachers College Record, 108(6), 1017.

Mutluoğlu, A. and Erdoğan, A. (2016). İlköğretim matematik öğretmenlerinin öğretim stili tercihlerine göre teknolojik pedagojik alan bilgisi (tpab) düzeylerinin incelenmesi. Ulusalarası Toplum Araştırmaları Dergisi, 6 0, 100-124.

Niess, M. L. (2005). Preparing teachers to teach science and mathematics with technology: developing a technology pedagogical content knowledge. Teaching and Teacher Education, 21(5), 509-523.

Oktay, S. and Çakır, R. (2012). İlköğretim öğretmelerinin teknoloji kullanımları ve teknolojiye yönelik tutumları arasındaki ilişkinin incelenmesi. X. Ulusal Fen Bilimleri ve Matematik Eğitimi Kongresi, 27-30.

Öz, H. (2015). Assessing pre-service English as a foreign language teachers' technological pedagogical content knowledge. International Education Studies, 8(5), 119-130.

Öztürk, E. (2013). Sınıf öğretmeni adaylarının teknolojik pedagojik alan bilgilerinin bazı değişkenler açısından değerlendirilmesi. Uşak Üniversitesi Sosyal Bilimler Dergisi, 2013(13).

Pamuk, S. (2012). Understanding preservice teachers' technology use through TPACK framework. Journal of Computer Assisted Learning, 28(5), 425-439.

Pamuk, S., Çakır, R., Ergun, M., Yılmaz, H. B. and Ayas, C. (2013). Öğretmen ve öğrenci bakış açısıyla tablet PC ve etkileşimli tahta kullanımı: FATİH Projesi değerlendirmesi. Kuram ve Uygulamada Eğitim Bilimleri Dergisi, 13(3), 1799-1822.

Reagin, J. (2004). Theoretical and practical applications of emergent technology in ELT classrooms; How the 'Blog' can change English Language Teaching. Teaching English in China, 3, 107.

Ruthven, K., Hennessy, S. and Deaney, R. (2005). Incorporating internet resources into classroom practice: pedagogical perspectives and strategies of secondary-school subject teachers. Computers \& Education, 44(1), 1-34.

Sancar-Tokmak, H., Konokman, G. Y. and Yelken, T. Y. (2015). Mersin Üniversitesi okul öncesi ögretmen adaylarının teknolojik pedagojik alan bilgisi (TPAB) özgüven algılarının incelenmesi. Ahi Evran Üniversitesi Kırşehir Eğitim Fakültesi Dergisi, 14(1), 35-51. 
Semiz, K. and İnce, M. L. (2012). Pre-service physical education teachers' technological pedagogical content knowledge, technology integration self-efficacy and instructional technology outcome expectations. Australasian Journal of Educational Technology, 28(7).

Serin, K. M. and Buluç, B. (2014). Sınıf öğretmenlerinin değer algıları ile örgütsel vatandaşlık davranışları arasındaki ilişki. Kastamonu Eğitim Dergisi, 22(1), 273-290.

Shulman, L. (1987). Knowledge and teaching: foundations of the new reform. Harvard Educational Review, 57(1), 1-23.

Seal, K. C. and Przasnyski, Z. H. (2001). Using the World Wide Web for teaching improvement. Computers \& Education, 36(1), 33-40.

Slough, S. W. and Chamblee, G. E. (2000). Implementing technology in secondary science and mathematics classrooms: A perspective on change. In Society for Information Technology \& Teacher Education International Conference (pp. 1021-1026). Association for the Advancement of Computing in Education (AACE).

Solak, E. and Çakır, R. (2014). Examining Preservice EFL Teachers' TPACK Competencies in Turkey. Journal of Educators Online, 11(2).

Şad, S. N., Açıkgül, K. and Delican, K. (2015). Senior preservice teachers' senses of efficacy on their technological pedagogical content knowledge (TPACK). Journal of Theoretical Educational Science, 8(2), 204-235.

Teo, T. (2006). Attitudes toward computers: A study of post-secondary students in Singapore. Interactive Learning Environments, 14(1), 17-24.

Teo, T. (2008). Pre-service teachers' attitudes towards computer use: A Singapore survey. Australasian Journal of Educational Technology, 24(4).

Timur, B. and Taşar, M. F. (2011). Teknolojik pedagojik alan bilgisi öz güven ölçeğinin (TPABÖGÖ) Türkçe'ye uyarlanması. Gaziantep University Journal of Social Sciences, 10(2).

Warschauer, M. (2002). A developmental perspective on technology in language education. TESOL quarterly, 36(3), 453-475.

Yavuz, S. (2005). Developing a technology attitude scale for pre-service chemistry teachers. The Turkish Online Journal of Educational Technology - TOJET, 4 (1), 17-25.

Yeh, Y., Hsu, Y., Wu, H., Hwang, F. and Lin, T. (2013). Developing and validating technological pedagogical content knowledge-practical (TPACK-practical) through the delphi survey Technique. British Journal of Educational Technology, 44(6), 1-16

Yıldırım, A. and Şimşek, H. (2013). Sosyal Bilimlerde nitel araştırma yöntemleri. Ankara: Seçkin Yayıncilik. 


\section{İngilizce öğretmenlerinin teknolojik pedagojik alan bilgisi becerileri ile teknolojiye yönelik tutumları arasındaki ilişkinin incelenmesi}

\section{$\ddot{O} \mathbf{z}$}

Günden güne hayatımıza giren ve eğitim alanında da etkisini gösteren teknoloji yabancı dil öğretimi ve öğreniminde önemini hissettirmiştir. Bu çalışmada, İngilizce öğretmenlerinin Teknolojik Pedagojik Alan Bilgisi (TPAB) becerileri ile teknolojiye yönelik tutumları arasındaki ilişkinin incelenmesi amaçlanmıştır. Ayrıca araştırmada, İngilizce öğretmenlerinin TPAB becerileri ve teknolojiye yönelik tutumlarının cinsiyet, FATİH Projesi eğitimi almış olma durumu ve mesleki deneyim değişkenlerine göre farklılaşıp farklılaşmadığı incelenmiştir. Araştırma, Türkiye'nin 81 ilinde görev yapan 721 İngilizce öğretmeni ile gerçekleştirilmiştir. Çalışmada ilişkisel tarama deseni kullanılmıştır. Veri toplama araçları olarak "TPAB Uygulama Ölçeği" ve "Teknolojiye Yönelik Tutum Ölçeği" kullanılmıştır. Verilerin analizinde aritmetik ortalama, standart sapma, t testi, ANOVA ve Pearson Çarpım Momentler Korelasyon Katsayısı kullanılmıştır. Çalışma sonucunda, İngilizce öğretmenlerinin TPAB becerilerinin ve teknolojiye yönelik tutumlarının yüksek düzeyde olduğu belirlenmiştir. İngilizce öğretmenlerinin teknolojiye yönelik tutumları cinsiyete, FATİH Projesi eğitimi alma durumlarına ve mesleki deneyime göre anlamlı farklılık göstermezken; kadın ve FATİH Projesi eğitimi alan öğretmenlerin TPAB becerilerinin daha yüksek olduğu, fakat öğretmenlerin TPAB becerilerinin mesleki deneyime göre farklılaşmadığı belirlenmiştir. Ayrıca, öğretmenlerin TPAB becerileri ile teknolojiye yönelik tutumları arasında düşük düzeyde, pozitif ve anlamlı bir ilişkinin olduğu sonucuna ulaşılmıştır.

Anahtar sözcükler: Teknolojik pedagojik alan bilgisi (TPAB), teknolojiye yönelik tutum, İngilizce öğretmenleri; teknoloji; Fatih projesi

\section{AUTHOR BIODATA}

Dr. İshak Kozikoğlu is an Assistant Professor in the Department of Educational Sciences, Division of Curriculum and Instruction, at Van Yüzüncü Yıl University, Turkey.

Nuri Babacan is currently working as an English teacher in Van and studying his master degree at Van Yüzüncü Y1l University, Department of Computer Education and Instructional Technology. 